\title{
Student Teams-Achievement Divisions (STAD) in Enhancing Speaking Performance among English as Second Language (ESL) Learners: A Critical Review
}

\author{
Izyan Safira Ibrahim, Nor Hafizah Adnan* \\ Faculty of Education, Universiti Kebangsaan Malaysia, Bangi, Malaysia \\ Email: ^norhafizah@ukm.edu.my
}

How to cite this paper: Ibrahim, I. S., \& Adnan, N. H. (2019). Student TeamsAchievement Divisions (STAD) in Enhancing Speaking Performance among English as Second Language (ESL) Learners: A Critical Review. Creative Education, 10, 2840-2849.

https://doi.org/10.4236/ce.2019.1012210

Received: October 21, 2019

Accepted: November 26, 2019

Published: November 29, 2019

Copyright $\odot 2019$ by author(s) and Scientific Research Publishing Inc. This work is licensed under the Creative Commons Attribution International License (CC BY 4.0).

http://creativecommons.org/licenses/by/4.0/

\begin{abstract}
In this review, the authors critically examined the potential of Student TeamsAchievement Divisions (STAD) in enhancing student's speaking performance among English as Second Language (ESL) learners. Specifically, the cooperative language learning concept that emerged in the 2000s, including procedures of implementing STAD and teaching speaking through STAD, were discussed. The authors examined conceptualizations of this model as well as related research. This review aimed to improve our understanding of STAD in enhancing speaking performance as well as teamwork satisfaction among ESL learners, provide a comprehensive discussion of current discourse, and offer major directions for future research.
\end{abstract}

\section{Keywords}

Student Teams-Achievement Divisions, Speaking Performance, Cooperative Language Learning, Teamwork Satisfaction, English as Second Language

\section{Introduction}

The importance of English in globalization has made it the most in demand language to be learned worldwide. However, learning English as a second language is not an easy task since one has made their first language as a comfortable medium to communicate. Some learners might not have enough exposure to English as a second language which causes the learning to be a bit harder for them. This situation can be equated to the students in non-native English speaking countries, for instance Malaysia, who have received maximum exposure of Eng- 
lish as the second language from primary to secondary school. Although they have learned the language for years, they are still having problem and difficulties in using the language.

\section{The Theory of Speaking}

The ability to speak is often considered as the most vital part since it is the basis for communication. Speaking may cover many aims such as daily conversation, talking to the employer, asking for something, conveying messages, and others. The term of speaking has been defined by many experts. (Richards \& Renandya (2008) proposed that speaking is one of the core elements of communication. Kayi (2006) suggested speaking is the process of building and sharing meaning verbally and non-verbally, in a various context.

In addition, Brown (2001) advocated that when someone can speak a language, it means they can carry on the conversation in a reasonable manner. Spratt, Pulverness, \& Williams (2005) added that speaking is a productive skill which involves speech as a medium to express the intended meaning. Richards \& Renandya (2008) stated five components in proficiency rating: accent, grammar, vocabulary, fluency, and comprehension in conversation performance. Even though there are a few other components in oral communication that support speaking skills, those five components are more important in creating a communication or delivering information.

\section{Cooperative Language Learning}

In a traditional English classroom, the teachers usually use textbooks as teaching materials. This method does not involve students to participate actively in the classroom activities, permitting only one-way of interaction and learning. This method is also well-known for teacher-centeredness, which is teachers give instructions and students finish the given tasks. However, with fast and sophisticated development in field of education, these teaching styles have been seen as a non-realistic approach to students. Thus, cooperative learning is one of the effective approaches which could assist students and teachers in creating more meaningful learning. Cooperative learning was introduced by Jean Piaget and Lev Vygotsky based on developmental theories, highlighting the significance of discussion and joint problem solving among peers.

In recent years, cooperative learning has emerged as an instructional practice and significant concept in the field of second language education. This statement is supported by McCafferty, Jacobs, \& Iddings (2006) that claimed cooperative learning arose in mainstream education as an attempt to address such problems and help student-to-student interaction. According to Jolliffe (2007), people may think cooperative learning requires students to work together in small groups to support others and thus improving their own learning. However, the scenario is not quite accurate since there are many variations of cooperative learning.

Most researchers agree that to be cooperative, learning can be made up of 
many key elements, including positive interdependence and individual accountability. For positive interdependence or as the given analogy, "we sink or swim together," requires each student in a small group to work in a way that each group members need the other's cooperation to complete the task. While for individual accountability or "no hitchhiking" indicates that each member of the group is accountable for completing his or her part of the work. It is important that nobody can be a free rider or sleeping partner on the work of others. This method requires each member of the group to build a sense of being responsible to learn and help the other members in the group to learn at the same time. The next element then deals with interpersonal skills, such as listening to others, encouraging, achieving consensus, conflict solving, and valuing others.

In contrast, Johnson, Johnson, \& Smith (2006) identified two components of cooperative learning, which is promotive interaction and group processing. The promotive interaction refers to the interaction of students in helping each other to accomplish the task and the group's shared goals. Referring to Johnson \& Johnson (2008), students are needed to interact verbally with one another in the learning task. Also, they are encouraged to explain things among each other, teach, and provide each other with support, help, and encouragement. The group processing demands group members to assess their functions and benefactions to the success of all tasks. It focuses on positive actions and behaviors rather than negatives ones as it involves students' way of thinking and learning.

Using cooperative learning as a teaching and learning strategy does not only promote cognitive development but also plays a significant role in the development of social and personal skills that could help students in the future. This statement is agreed by Tang \& $\operatorname{Lim}$ (2018) who claimed learning experiences that are focusing on engaging and contextual interaction would encourage student's learning. Group learning as collaborative learning allows students to get to know each other that composes part of their experience during teaching and learning process. By encouraging students to learn together, learning communities have involved the students to participate in both socially and intellectually in ways that promote cognitive development. This approach is very important as students could be equipped with knowledge and skills to fill the demand for higher thinking order thinking skills in the 21 st century world.

\section{Student Teams-Achievement Division (STAD)}

According to Aryani (2016), STAD is one of the simplest cooperative learning and has gone through under a lot of research by previous scholars. STAD is also commonly used to teach a wide range of subjects and grades. The five basic key components of STAD are the class presentation, teams, quizzes, individual improvement scores, and team recognition.

- As for class presentation, materials will be presented in class, including lecture-discussion, direct instruction to tasks, and audio-visual presentations. Students need to focus on the presentations in order to help them understand 
the lesson completely. By doing so, they are expected to do well in quizzes.

- In STAD, each group will consist of four to five members, mixed in sex, race, ethnicity, and academic performance, in which they need to be responsible upon their team learning as well as preparing for quizzes. As STAD allows students to help each other, students in each group will do activities, such as discussion, comparing answer, and correcting mistakes of each other, helping them to do well for their team.

- After class presentation and team preparation, students will sit for the individual quiz and this time they have to work on their own. This method enables students to apply their own knowledge based on what they have learned.

- The marks are based on the student's improvement scores from previous quizzes. Points will be given to the group who has shown the improvement from earlier test.

- Team recognition then will be given to the team that manages to achieve the predetermined criteria. The team recognition may be in the form of badges, certificates, or any appropriate rewards.

\subsection{Procedures of Implementing STAD}

According to Slavin (1995), there are a few procedures in implementing STAD in the classroom:

1) Preparation: The first step is to design the learning materials that must be appropriate with the students. The materials can be designed by teachers, adapted from a textbook, or other relevant sources. Students then are grouped into few teams. Teachers must take into consideration their gender, race or ethnicity, and academic performance. The final stage is to determine the student's average score of the assessment or initial base scores.

2) STAD activities

- Teach: During activities, teachers will start with the lesson. The class presentation should consist of the opening, development, and guided-practice components.

- Team study: Students will work in their own group, learn the materials and complete the activities or tasks. The teacher must explain the advantages of working in groups.

- Test: Each student will take a quiz or test individually. The test scores will be used to determine the overall improvement of the individuals and the teams.

3) Assignation of new teams: The last procedure will be done after the assessment of activities. This procedure will give low-performance students an opportunity to learn with high-performance students. Team recognition is given in a form of certificates or rewards based on the individual improvement scores and team scores.

\subsection{Teaching Speaking through STAD}

There are some speaking activities that can be practiced in STAD. Adapted from 
Harmer (2005), the classroom speaking activities that mostly being used in communication continuum are:

1) Acting from script: For this activity, students act out the scenes from a play or their course book. Students could also act out dialogues that they have written by themselves in front of their classmates.

2) Communication games: This game is designed to provoke student's communication as it should be done with a partner. The student will communicate with their partner to solve puzzles, describe, draw, arrange or find for similarities and differences between pictures.

3) Discussion: This activity involves the students in giving opinion or thought. Students are usually reluctant to give their opinion in front of the class due to low self-esteem. Through this activity, they will have the opportunity in sharing their opinion through a small group formation.

4) Prepared talks: Before presentation, students will be asked to prepare on what they will explain or share.

5) Questionnaires: Questionnaires are useful because students are referred to the design questionnaire on any related appropriate topics. By doing this, students can discuss or prepare their presentations, while the teacher helps students in designing the process.

6) Simulation and role play: Simulation and role-play can be used to train general oral fluency or train the students for specific situations. This approach can also be useful especially when the students are studying English for a specific purpose.

7) The roles of the teacher: In this activity, teachers are required to play a different role during the speaking activities in order for improving students' fluency. There should be three roles in the activity: the prompter, the participants, and the feedback provider.

Overall, the classroom activities listed above can be used in teaching speaking to ESL learners. Harmer (2005) claimed that a small group consists of five students evokes greater participation and involvement as opposed to larger groups. Thus, this approach could form a good teamwork in accomplishing the given tasks. On the other hand, Broughton, Brumfit, Flavell, Hill, \& Pincas (2003) proposed a few general functions for the speaker in learning the language for communication. These general functions show that in speaking, the speaker will learn on how to convey and practice based on directive: polite, aggressive, pleased or angry. The speaker will also learn on how to deliver the information appropriate to the situation, in which the speaker can control and influence the listener in some way. One of the advantages of learning the function of speaking is the information transfer will occur without miscommunication, thus students can create a good communication with others.

\subsection{Related Studies on STAD}

Slagle (2009) conducted an action research to examine if the implementation of 
the cooperative learning strategy, STAD, could improve academic achievement in a secondary social studies classroom. The instruments adopted in this research were researcher-designed worksheets, quizzes, and test. The findings showed that students' academic achievement increased after the implementation of STAD. This research concluded that cooperative learning using STAD model had a positive impact on academic achievement among most secondary social studies participants.

Majoka, Khan, \& Syed (2011) conducted a research using STAD as an active learning strategy in Mathematics classroom at the secondary level. The experiment lasted for a period of 10 weeks with one group was provided with STAD as treatment, while another group received the traditional teaching approach. The findings showed that STAD was more effective instructional paradigm if compared to the traditional teaching method. The researcher noted that the difference between both groups can be accredited to the provision of small group work in STAD that is featured by mutual interference of teammates, individual accountability, peer pressure due to common goals, continuous assessment and performance rewards. All of these criteria grounded in STAD encourage students to be responsible for their learning.

Wyk (2012) implemented a quasi-experimental research to investigate whether there was any significant difference between the means of the pre-test and post-test of the students in STAD and control's group achievement, attitude, and motivation. For motivation scale, there were five dependent variables developed to measure student's motivation scale: achievement goal orientation, self-efficacy, intrinsic motivation toward economics, and cognitive processing. As for the modular test, there were also five subject contents to measure achievement: curriculum statement objectives, economic concepts, microeconomics, economic development, and entrepreneurship. The researcher concluded that using STAD as a teaching technique produced positive outcomes on the economic literacy level, as well as promoted changes in students' perceptions and motivations.

Wyk (2015) conducted the effectiveness of STAD as a teaching strategy on grade 10 learners' economic knowledge. The methodology adopted in this research was quasi experimental to see the difference between students who were taught using STAD and received direct-instructional method. Using STAD, teachers presented an ill-structured problem of unemployment and students worked in groups to find the solutions. Students then were asked to complete a forty-response-item multiple choice questionnaire on economics. This research indicated that STAD enhanced grade 10 learner's knowledge and learning of Contemporary Economics Issue. The teachers also considered STAD as an effective teaching strategy.

Ferina (2015) executed a quasi-experimental study on STAD as a Strategy of Teaching Reading Comprehension in Junior High School. The objective of this research was to investigate whether there was a significant difference in students' achievement in reading comprehension taught using STAD and lecture method. 
A set of reading comprehension test was used as pre-test and post-test for both groups. The experimental group experienced the common STAD procedures such as class presentation, team study, individual quiz, and reward. The researcher noted that students who were taught using cooperative learning, STAD, learned and worked together in team, cooperated with peers to understand the materials, and gave attention to the class presentation in order to perform better in quizzes.

Wiraningsih \& Budi (2016) carried out a massive research on developing speaking skill through STAD at Grade XI students. This pre-experimental design aimed at developing student's speaking skill through STAD. The cluster sampling was used to sort 88 students comprising one major science group and two from social science groups. Overall, the research showed that students' speaking skills in terms of fluency and comprehensibility were improved. The researchers also claimed that STAD helps students to speak confidently. STAD facilitates students' learning as they can discuss and collaborate with peers in groups, improving their communication skills which in turn leads to meaningful learning.

Wardani \& Hermawati (2016) implemented a research driven by the Classroom Action Research, titled "Improving the Tenth Grade Students' Speaking Ability." The study aimed to find out if the STAD method can improve speaking ability of the tenth-grade students. This study was carried out in four steps: planning the action and preparing the material and tools for the research activities, acting in which the students worked in groups, observing students' understanding, and reflecting to analyze the result of observation. STAD greatly improved students' communication skills through peer support when they have difficulties and problems in learning English.

Faramarz \& Mowlaie (2017) carried out a study on the effect of using STAD technique on improving Iranian Elementary EFL learner's reading comprehension. The mean score of the experimental group in the pre-test is 32.04 while 35.79 for their post-test which showed an improvement. The mean score for the control group also showed improvement from 32.39 to 33.00 , however, the value was not as high as the value gained from the experimental group. The researchers also stated that STAD would be more beneficial in crowded classes because it can prevent the inherent limitation of time and resources imposed on teacher-centered classes. Thus, STAD can be regarded as a good practice for both second and foreign language reading comprehension classes.

Jamaludin \& Mokhtar (2018) implemented an achievement test study to compare experimental group and control group through quasi pre-test and post-test. Driven by the aim to evaluate students' attitude towards tourism geography subject, the researcher carried out the STAD using Kemnis and McTaggart's Participatory Action Theory. An attitude inventory scale and teamwork satisfaction were measured for understanding students' perceptions on the STAD teaching technique. The researchers reported that STAD technique improved students' achievement tests, as well as their attitude and teamwork. Students found to be more focused and motivated as their roles in groups were rec- 
ognized by peers.

\section{Conclusion}

The findings of the related studies can be categorized into three aspects, namely effectiveness, student's attitude, and teamwork. To zoom into the effectiveness of STAD, most related studies reported that students who experienced STAD received significantly higher scores based on their post-test result. Slagle (2009) concluded that cooperative learning using STAD had a slight increase in academic achievement among secondary social studies participants. Widhyastika, Sutarsyah, \& Suparman (2017) also claimed that STAD was effective since it can be applied with a heterogeneous student's ability, providing students chances to collaborate with members in groups to solve learning problem. Wyk (2015) stated that STAD enhanced grade 10 students' knowledge in Contemporary Economic Issue.

In terms of student's motivation and attitude toward STAD, Wardani \& Hermawati (2016) reported that STAD could affect student's ability as they were more confident since peers could help them when they have difficulty in English. Jamaludin \& Mokhtar (2018) noticed that students were more focused and motivated as their roles in groups were recognized by peers. Similarly, Wyk (2012) concluded that STAD as a teaching technique promoted changes in students' perceptions and motivations in economic literacy level. Wiraningsih \& Budi (2016) found that STAD helped students to speak confidently during evaluation. Majoka, Khan, \& Syed (2011) emphasized that the features of STAD, such as mutual interference of teammates, individual accountability, peer pressure due to common goals, continuous assessment, and performance rewards allowed students to be more responsible with their learning.

Some related studies also obtained finding on teamwork using STAD. Widhyastika, Sutarsyah, \& Suparman (2017) asserted that STAD works well with students since it can be applied with a heterogeneous students ability, providing students chances to collaborate with their members in groups. Wiraningsih \& Budi (2016) also agreed that STAD facilitated students' learning as they could discuss and perform tasks in groups, allowing them to speak actively and develop meaningful learning. Ferina (2015) added that students who were taught using cooperative learning or STAD, learned and worked together in teams, collaborated to understand the materials, and paid attention to class presentation, which developed an impressive achievement in the reading class.

In this review, we examined the progress and trends of the past decade that could offer directions for future research. The authors hope this review offers greater insights into the cooperative language learning and encourages further research on STAD among ESL learners in enhancing speaking performance with effective instructional design (Adnan \& Ritzhaupt, 2018; Adnan, 2018) and alternative assessment such as usage of learning analytics and network diagrams (Norman, Nordin, Din, Ally, \& Dogan, 2015; Norman, Nordin, Yunus, \& Ally, 
2018; Hashim, Yunus, \& Embi, 2018).

\section{Funding}

This research is supported by the Universiti Kebangsaan Malaysia-Dana Pecutan Penerbitan FPend (Grant No. PP-FPEND-2019) and Dana Penyelidikan FPEND (Grant No. GG-2019-010).

\section{Conflicts of Interest}

The authors declare no conflicts of interest regarding the publication of this paper.

\section{References}

Adnan, N. H. (2018). An Interactive Mobile Augmented Reality Textbook for Learning Biology. Journal of Advanced Research in Dynamical and Control Systems, 10, 17191725.

Adnan, N. H., \& Ritzhaupt, A. D. (2018). Software Engineering Design Principles Applied to Instructional Design: What Can We Learn From Our Sister Discipline? TechTrends, 62, 77-94. https://doi.org/10.1007/s11528-017-0238-5

Aryani, D. (2016). The Use of Cooperative Learning Stad to Improve Speaking Skills of Accounting Program Students Grade Xi in SMK N 1 Depok in the Academic Year of 2013/2014. Universitas Negeri Yogyakarta Thesis.

Broughton, G., Brumfit, C., Flavell, R., Hill, P., \& Pincas, A. (2003). Teaching English as a Foreign Language. Abingdon-on-Thames: Routledge \& Kegan Paul Ltd Fq.

Brown, H. D. (2001). Teaching by Principles; an Interactive Approach to Language Pedagogy (2nd ed.). New York: Addison Wesley Longman, Inc.

Faramarz, S., \& Mowlaie, B. (2017). The Effect of Using the Student Teams Achievement Division (STAD) Technique on Improving Iranian Elementary EFL Learner's Reading Comprehension. Journal of Applied Linguistic and Language Research, 4, 51-64.

Ferina, F. (2015). Stad as a Strategy of Teaching Reading Comprehension in Junior High School. Journal of English Education and Linguistics Studies, 2, 29-43. https://doi.org/10.30762/jeels.v2i1.42

Harmer, J. (2005). The Practice of English Language Teaching. London: Pearson Education Limited.

Hashim, H., Yunus, M. M., \& Embi, M. A. (2018). Factors Influencing Polytechnic English as Second Language (ESL) Learners' Attitude and Intention for Using Mobile Learning. Asian ESP Journal, 14, 195-208.

Jamaludin, M., \& Mokhtar, M. F. (2018). Students Team Achievement Division. International Journal of Academic Research in Business and Social Sciences, 8, 570-577. https://doi.org/10.6007/IJARBSS/v8-i2/3966

Johnson, D. W., \& Johnson, R. T. (2008). Social Interdependence Theory and Cooperative Learning: The Teacher's Role. In R. M. Gillies, A. Ashman, \& J. Terwel (Eds.), Teacher's Role in Implementing Cooperative Learning in the Classroom (pp. 9-37). New York: Springer. https://doi.org/10.1007/978-0-387-70892-8_1

Johnson, D. W., Johnson, R. T., \& Smith, K. A. (2006). Active Learning: Cooperation in the College Classroom. Edina, MN: Interaction Book Company.

Jolliffe, W. (2007). Cooperative Leaning in the Classroom: Putting It into Practice. Lon- 
don: Paul Chapman Publishing.

Kayi, R. (2006). Teaching Speaking: Activities to Promote Speaking in a Second Language. The Internet TESL Journal, 12. http://iteslj.org/Techniques/Kayi-TeachingSpeaking.html

Majoka, M., Khan, M, \& Syed, I. H. S. (2011). Effectiveness of Cooperative Learning for Teaching Social Studies to Students with Different Ability at Elementary Level. Interdisciplinary Journal of Contemporary Research in Business, 2, 486-497.

McCafferty, S. G., Jacobs, G. M., \& Iddings, A. C. D. S. (2006). Cooperative Learning and Second Language Teaching. Cambridge: Cambridge University Press.

Norman, H., Nordin, N., Din, R., Ally, M., \& Dogan, H. (2015). Exploring the Roles of Social Participation in Mobile Social Media Learning: A Social Network Analysis. The International Review of Research in Open and Distributed Learning, 16, 205-224. https://doi.org/10.19173/irrodl.v16i4.2124

Norman, H., Nordin, N., Yunus, M. M., \& Ally, M. (2018). Instructional Design of Blended Learning with MOOCs and Social Network Analysis. Advanced Science Letters, 24, 7952-7955. https://doi.org/10.1166/asl.2018.12464

Richards, J. C., \& Renandya, W. A. (2008). Methodology in Language Teaching: An Anthology of Current Practice. Cambridge: Cambridge University.

Slagle, D. R. (2009). The Use of Cooperative Learning Strategy STAD to Promote Academic Achievement in a High School Social Studies Class. Submitted to the Master of Arts in Education Programme of Defiance College in Partial Fulfilment of the Requirements for the Degree of Masters of Arts in Education. North Central Local Schools.

Slavin, R. E. (1995). Cooperative Learning: Theory, Research, and Practice (2nd ed.). Englewood Cliffs, NJ: Prentice Hall.

Spratt, M., Pulverness, A., \& Williams, M. (2005). The TKT (Teaching Knowledge Test) Course. Cambridge: Cambridge University Press.

Tang, S. F., \& Lim, C. L. (2018). Preparing the Next Generation of Teachers for 21st Century Education. Hershey, PA: IGI Global. https://doi.org/10.4018/978-1-5225-4080-9

Wardani, R. P., \& Hermawati, D. M. S. (2016). Improving the Tenth Grade Students' Speaking Ability by Using STAD at SMKN 5 Jember. In International Conference on Education Proceeding (Vol. 1, pp. 79-88). http://repository.unej.ac.id/handle/123456789/63200

Widhyastika, D. P., Sutarsyah, C., \& Suparman, U. (2017). Developing Student-Team Achievement Division (STAD) Technique to Encourage Student Reading Comprehension Achievement Based on Extrovert and Introvert Personality.

Wiraningsih, V., \& Budi, K. M. (2016). Developing Speaking Skill through STAD at Grade XI Students. E-Journal of English Teaching Society (ELTS), 4, 1-10.

Wyk, M. M. V. (2012). The Effect of the STAD-Cooperative Learning Method on Student Achievement, Attitude and Motivation in Economics Education. Journal of Social Science, 33, 261-270. https://doi.org/10.1080/09718923.2012.11893104

Wyk, M. M. V. (2015). Measuring the Effectiveness of Student Team Achievement Division as a Teaching Strategy on Grade 10 Learners' Economic Knowledge. International Journal of Educational Science, 10, 325-337.

https://doi.org/10.1080/09751122.2015.11917664 